\title{
PARADIGMA PENDIDIKAN SENI BERBASIS KARAKTER DALAM MUSIK MA'BADONG
}

\author{
Zefanya Sambira ${ }^{1}$, Alfa Kristanto ${ }^{2}$ \\ Universitas Negeri Semarang ${ }^{1}$ \\ zefanyasambira@gmail.com ${ }^{1}$
}

Sekolah Tinggi Theologia Abdiel Ungaran ${ }^{2}$

alfaomega.kristanto@gmail.com ${ }^{2}$

\begin{abstract}
Abstrak
Paradigma pendidikan seni berbasis karakter diharapkan mampu menjadi penyeimbang sisi intelektual manusia. Pendidikan seni dapat membentuk apresiasi, kreativitas, dan ekspresi peserta didik. Seni dikenal dan diketahui oleh manusia lewat perwujudan dan kreativitas penciptanya (seniman). Karakter dipahami sebagai kumpulan ciri-ciri tertentu yang secara sadar dapat berubah karena pengaruh dari dirinya sendiri bahkan pengaruh dari masyarakat yang seakan-akan menuntun pada perubahan. Pengembangan karakter yang sesuai akan membentuk intelektual dan budi pekerti individu menjadi seimbang. Aspek moralitas tersebut berupa budi pekerti dan nilai-nilai yang akan membentuk karakter seseorang sesuai dengan apa yang ada pada dirinya. Oleh karena itu, pendidikan seni berbasis karakter perlu diperhatikan dan dilakukan secara maksimal melalui media karya seni seperti misalnya musik Ma'badong. Musik Ma'badong merupakan musik yang digunakan dalam prosesi ritual kematian di Tana Toraja yang mengandung aspek musik dan nilai-nilai luhur yang dianut dalam kepercayaan Aluk To'dolo. Nilai-nilai yang terdapat dalam musik Ma'badong mampu menjadi sarana pembentukan karakter individu yang sesuai dengan masyarakatnya.
\end{abstract}

Kata kunci: karakter; ma'badong; paradigma; pendidikan seni

\begin{abstract}
The character-based arts education paradigm is expected to be able to balance the intellectual side of humans. Art education can shape the appreciation, creativity, and expression of students. Art is known and known by humans through the embodiment and creativity of its creator (artist). Character is understood as a collection of certain characteristics that can consciously change due to the influence of himself and even the influence of society that seems to lead to change. The development of the appropriate character will shape the intellectual and individual character to be balanced. The aspect of morality is in the form of character and values that will shape a person's character according to what is in him. Therefore, character-based arts education needs to be considered and carried out maximally through art media such as Ma'badong music. Ma'badong music is music used in the procession of the death ritual in Tana Toraja which contains aspects of music and noble values adhered to in the Aluk To'dolo belief. The values contained in Ma'badong's music are able to be a means of forming individual characters that are appropriate to the society.
\end{abstract}

Keywords: character; ma'badong; paradigm; art education

\section{Pendahuluan}

Pendidikan merupakan bagian penting dalam segala aspek kehidupan masyarakat. Pendidikan berperan penting dalam mengangkat harkat dan martabat manusia, sehingga pendidikan juga menjadi salah satu ujung tombak bagi kemajuan dan perkembangan sebuah negara. Undang-undang nomor 12 tahun 2012 pasal 1 tentang pendidikan tinggi menjelaskan bahwa pendidikan adalah usaha sadar dan terencana untuk mewujudkan 
suasana belajar dan proses pembelajaran agar peserta didik secara aktif mengembangkan potensi dirinya untuk memiliki kekuatan spiritual keagamaan, pengendalian diri, kepribadian, kecerdasan, akhlak mulia, serta keterampilan yang diperlukan dirinya, masyarakat, bangsa, dan negara.

Menurut Ki Hadjar Dewantara (1962), pendidikan adalah daya atau usaha untuk bertumbuh dan berkembangnya intelektual, budi pekerti (karakter), dan tubuh anak. Ketiga usaha tersebut seharusnya secara berkesinambungan menghidupi kebutuhan anak atau peserta didik menuju kesempurnaan hidup. Jika dilihat dari perspektif kebudayaan, pendidikan berfungsi untuk mempertahankan, melangsungkan, dan mengembangkan eksistensinya dengan adaptasi lingkungan sekitarnya (Triyanto 2017, p. 79).

Seni merupakan sesuatu yang memuat hal-hal transendental yang belum pernah diketahui kemudian dikenal lewat sebuah karya (Sumardjo, 2000). Artinya, seni dikenal dan diketahui oleh manusia lewat perwujudan dan kreativitas penciptanya (seniman). Wujud itu adalah sesuatu yang dapat diindera oleh manusia lewat apa yang dimilikinya. Sebagai contoh, wujud dari musik ialah suara atau bunyi, wujud dari tari ialah gerak, dan wujud dari rupa ialah garis. Ketiga wujud tersebut kemudian terbagi-bagi lagi sesuai dengan karateristik senimannya. Karya musik Bach akan berbeda dengan Mozart, tari kreasi Didik Thowok berbeda dengan tari kreasi penari lain, dan lukisan Affandi akan berbeda karateristiknya dengan pelukis lain. Semuanya itu, dalam istilah seni disebut sebagai keberagaman bentuk ekspresi estetik dalam wujud karya seni (Triyanto, 2017, p. 88).

Pendidikan seni merupakan salah satu program studi yang belum lama terbentuk, jika dibandingkan dengan program studi ataupun jurusan seni lainnya. Dalam pendidikan seni, fokus utamanya mengarah pada seni sebagai media pendidikan. Dengan kata lain, seni bukan lagi menjadi objek didik melainkan subjek didik dalam mengembangkan potensi peserta didik. Seni sebagai media pendidikan sebagai contohnya di dalam pendidikan non-formal yaitu masyarakat terlibat dalam permainan gamelan, baik untuk acara keagamaan maupun acara tradisi desa tertentu, karena menurut Kristanto (2019), berawal dari gamelan yang difungsikan sebagai hiburan kemudian fungsi itu mengalami perubahan yaitu gamelan digunakan untuk mendukung dalam ibadah minggu, artinya gamelan dapat difungsikan dalam ritual keagamaan. Sembari memainkan gamelan maka pengrawit tersebut sudah mempraktikkan pendidikan seni didalamnya. Diantaranya adalah terjadinya interaksi selama proses latihan sehingga tertanam nilai-nilai kebersamaan yang 
dapat menumbuhkan sikap empati kepada sesamanya. Soetedja (dalam UPI, 2007) menjelaskan bahwa hakikat dari pendidikan seni adalah seni menjadi pembentuk manusia. Pembentukan tersebut melalui pengalaman estetis yang didapatkan, maupun yang diterimanya lewat pendidikan formal, informal, dan non formal. Pengalaman estetis tersebut berupa perasaan, pikiran, dan penginderaan manusia. Maka tidak heran jika dalam pembelajaran seni sisi intelektualitas kurang ditonjolkan-berupa sifat rasionalistik.

Pendidikan karakter menurut Suryabrata (1988) erat kaitannya dengan psikologi kepribadian, ilmu watak, ilmu perangai, dan ilmu kejiwaan. Karakter merupakan sistem yang relatif permanen dan bukan non-insting, yang menghubungkan dirinya dengan dunia manusia, bahkan dengan alam (Fromm dalam Feist, 2010). Dengan kata lain, tindakan yang dilakukan oleh seorang manusia bersesuaian dengan karakter yang ia miliki, sehingga berbagai penyimpangan yang dilakukan oleh manusia, semata-mata bukan wujud karakter, melainkan naluri (Ratna, 2014).

Perkembangan pendidikan karakter telah menghasilkan berbagai karateristik yang sering terdengar dan ditemukan dalam kehidupan sehari-hari seperti misalnya pendidikan budi pekerti, pendidikan kewarganegaraan, pendidikan moral Pancasila, pendidikan kesejahteraan keluarga (PKK), serta bimbingan dan penyuluhan (BP). Semuanya itu merupakan bagian dari pendidikan karakter yang bercirikan pola dan tingkah laku positif, atau dengan kata lain pendidikan karakter sebagai penyeimbang kata dan perbuatan seseorang.

\section{Hubungan Pendidikan dengan Pembentukan Karakter}

Pendidikan, khususnya di Indonesia secara formal dimulai ketika berakhirnya penjajahan kolonial Belanda, atau lebih tepatnya secara menyeluruh dimulai sejak kemerdekaan Indonesia. Proses pendidikan yang ada pada saat itu mengarah pada usaha untuk mencapai cita-cita masyarakat dalam mengisi kemerdekaan. Namun proses dan perkembangan pendidikan pada saat itu juga tidak terlepas dari hambatan yang dihadapi sebagai proses globalisasi. Pendidikan dipahami sebagai usaha sadar untuk mengubah sikap dan mengembangkan potensi. Untuk itu, pendidikan harus mengarah pada kebenaran objektif sebagai bentuk eksistensi pendidikan pada ilmu pengetahuan (Foucault, 2012). Pendidikan terfokus pada kebenaran ilmu pengetahuan, toleransi, dan kesetaraan bukan tunduk dan patuh pada kapitalisme yang penuh dengan hegemoni dan kekuasaan. Hal inilah yang dikatakan Bourdieu (1992) bahwa bentuk hegemoni adalah kekerasan simbolik 
yang telah dilakukan pemerintah. Sebagai akibat dari hegemoni tersebut, pengembangan pendidikan yang ada pada saat ini lebih fokus pada intelektual seseorang, yang tercermin dari penguasaan dan pemahamannya terhadap sains, teknologi, dan ekonomi. Hal inilah yang mengakibatkan manusia terlibat korupsi, kolusi, dan nepotisme dalam jabatan dan kekuasaannya. Maka dari itu, pendidikan sejak awal harus bersifat sebagai penyeimbang antara aspek intelektual dan aspek moralitas. Aspek moralitas tersebut berupa budi pekerti dan nilai-nilai yang akan membentuk karakter seseorang sesuai dengan apa yang ada pada dirinya. Secara umum pembentukan karakter yang sudah ada, mula-mula berawal dari lingkungan yang paling kecil yakni keluarga.

Secara etimologi, istilah karakter berasal dari bahasa Yunani "karasso" yang berarti format dasar atau sidik jari (Drench dalam Mayer, J.D. \& Cobb, 2000). Menurut Liebman (dalam Mayer, J.D. \& Cobb, 2000) istilah karakter berasal dari bahasa Yunani "charassein" yang berarti membuat tajam. Secara umum, pengertian karakter terbagi berdasarkan sifatnya yaitu sifat deterministik dan non-deterministik. Karakter berdasarkan sifat deterministik merupakan kumpulan kondisi rohani yang sudah diterima (Mayer, J.D. \& Cobb, 2000). Dalam hal ini, karakter dipahami sebagai kondisi yang diterima, tidak dapat diubah dan tanda yang membedakan seseorang dengan yang lainnya. Karakter berdasarkan sifat non-deterministik merupakan proses seseorang dalam menentukan dan mengatasi kondisi dirinya hingga mencapai kesempurnaan (Perez, 2005).

Membentuk karakter seseorang tidak semudah membalikkan telapak tangan. Proses pembentukan karakter akan saling berbenturan dengan kejiwaan dan pendidikan. Karakter dipahami sebagai kumpulan ciri-ciri tertentu yang secara sadar dapat berubah, sebagai akibat pengaruh dari dirinya sendiri bahkan pengaruh dari kelompok atau masyarakat yang seakan-akan menuntun pada perubahan. Secara umum, pembentukan karakter seseorang dibagi menjadi tiga bagian yakni pembentukan individu, keluarga, dan bangsa. Pembagian ini bukan hanya sekedar ruang lingkup atau batasan pembentukan karakter, namun juga berbicara tentang bagaimana proses pendidikan itu benar-benar dapat dihayati seseorang dalam perkembangannya.

\section{Pembentukan Karakter Individu}

Dalam pandangan ilmu sosiologi dan antropologi, individu merupakan unsur terkecil dalam kehidupan manusia. Jika dipandang dari kacamata psikologi, individu diartikan sebagai unsur kejiwaan dimana ia bertindak sebagai subjek dalam mewujudkan 
pendidikan, yang dalam artian ini disebut pendidikan karakter (Ratna 2014). Sebagai contoh dalam mengejarkan tugas (PR), anak umumnya dituntun oleh orang tua dengan membuka kembali buku atau catatan ketika di sekolah. Namun setelah itu orang tua akan membiasakan anaknya untuk secara mandiri menyelesaikan tugas sesuai kemampuannya, meskipun kenyataannya orang tua masih tetap menjadi guru kedua bagi anaknya. Hal ini juga secara perlahan membuat anak tersadar ketika diberi tugas di sekolah. Ia akan secara mandiri mengerjakan tugasnya, baik tugas pribadi maupun tugas kelompok. Ketika dalam tugas kelompok, anak akan berusaha menyesuaikan dirinya dengan teman-temannya, sehingga ia tidak perlu lagi bersifat kekanak-kanakan seperti di rumahnya.

Sigmund Freud (dalam Hall, 1980) menurut teori kepribadiannya membagi personalitas manusia menjadi dua bagian yaitu alam sadar dan alam bawah sadar. Freud menjelaskan setiap individu digerakkan oleh keinginan, obsesi, bahkan hawa nafsu yang terekam di dalam memori individu sebagai proses masa lalu. Keinginan dan kemauan tersebut menurut Freud perlu dikendalikan sesuai dengan konteksnya agar hal tersebut lebih bersifat positif, bukan sebaliknya. Dari sini, pendidikan sejak awal memiliki peranan penting dalam pembentukan karakter, terutama pembentukan karakter individu. Sejak kecil, perilaku yang dilakukan individu menjadi pengalaman yang berkesan, seperti misalnya sebelum makan harus cuci tangan terlebih dahulu, maka secara perlahan menjadi kebiasaan yang tak boleh dilewatkan. Inilah yang menjadi keutamaan dari pendidikan dasar, sebab individu sejak awal ditanamkan pemahaman dasar untuk masuk pada tahap perkembangan selanjutnya.

\section{Pembentukan Karakter Keluarga}

Dalam dunia pendidikan, keluarga merupakan bagian dari pendidikan informal dimana seorang anak pertama kali mendapat didikan dari kedua orang tuanya. Dulunya, keluarga dipahami sebagai penganut paham yang sama dalam suatu lingkungan terkecil. Saat ini, setiap anggota keluarga dapat bebas menentukan pilihan dalam hidupnya, termasuk keyakinan dan ideologinya. Sejatinya, pembentukan keluarga merupakan usaha mempertahankan stabilitas keluarga dan menjadi teladan bagi anggota keluarga yang lainnya (Ratna, 2014). Stabilitas tersebut diharapkan akan terus berlanjut hingga generasi selanjutnya, sehingga akan ada kesan unik dalam keluarga, keteladanan dalam keluarga mula-mula diterapkan oleh orang tua, kemudiam diikuti oleh anak-anaknya. 
Kunci utama sebagai penentu terbentuknya karakter anak dalam keluarga adalah orang tua. Sebagai orang tua, tidak cukup hanya menafkahi dan mencukupi kebutuhan keluarga dari segi ekonomi, namun perlu juga memperhatikan pendidikan yang layak bagi anak. Perlu disepakati bahwa ibu merupakan anggota keluarga yang paling dekat dengan anak. Ibu yang melahirkan, ibu sering berada di rumah, dan ibu selalu menyiapkan kebutuhan pribadi anak. Hal inilah yang mendasari French (1985) bahwa kaum perempuan sejak zaman prasejarah bersifat matrifokal atau matrisentris yang berarti menjaga dan menguasai anak agar dapat mandiri. Peran ayah dalam pembentukan karakter anak dalam keluarga dirasa belum dapat setara dengan peran seorang ibu. Ayah dalam sebuah keluarga lebih cenderung fokus bekerja untuk memenuhi kebutuhan keluarga. Sudah saatnya mulai sekarang perlu dihayati dan diterapkan bahwa peran keluarga dalam pembentukan karakter anak. Di lain pihak, pembentuk karakter dalam keluarga sedang mempersiapkan masa depan anak dan memaksimalkan sumber daya anak.

\section{Pembentukan Karakter Bangsa}

Pembentukan karakter bangsa adalah gabungan dari pembentukan karakter individu dan karakter keluarga. Karakter bangsa tercermin dalam masyarakatnya sebagai bentuk nilai karakter tertinggi dalam hidupnya. Dari segi durasi, pembentukan karakter bangsa membutuhkan waktu yang paling lama dibanding dengan yang lainnya (Ratna, 2014). Pembentukan karakter bangsa disisipi disiplin, kreativitas, dan cita-cita bangsa yang sudah lama terpendam. Menurut Jung (1949), semua karateristik yang ada masuk dalam ketidaksadaran filogenesis, yang berarti diwariskan melalui spesies secara rasial. Istilah bangsa di Indonesia lebih dipahami sebagi negara nasional. Kartodirjo (1990) menjelaskan bahwa negara nasional terbentuk akibat situasi politik, ekonomi, dan sosial budaya. Selain itu Koentjaraningrat (1990) menjelaskan kesatuan manusia terikat oleh keseragaman kebudayaan yang dapat meluas dan menyempit tergantung keadaan. Namun politik memiliki pengaruh yang cukup kuat dalam menentukan arah pembangunan nasional. Dalam perkembangannya, sifat nasionalisme merupakan pendongkrak semangat Indonesia yang terwujud dalam Sumpah Pemuda dan Proklamasi Kemerdekaan. Sifat nasionalisme memacu pembentukan karakter bangsa dari Sabang hingga Merauke sebagai keputusan mutlak yakni bangsa Indonesia. Wujud dari hasil pembentukan karakter bangsa dapat dilihat dalam kehidupan masyarakat Indonesia seperti gotong royong, mendahulukan 
kepentingan umum, menghormati orang yang lebih tua, dan menghargai perbedaan agama, latar belakang, bahkan adat-istiadat.

\section{Antara Seni dan Pendidikan Seni}

Seni adalah sesuatu yang selalu ada dalam kehidupan manusia, meskipun ternyata kehadirannya tidak begitu dianggap bahkan cenderung identik dengan sesuatu yang abstrak. Seni yang ada saat ini-seni musik, seni tari, seni rupa, dan seni teater-dianggap sebagai hiburan semata atau sekedar pelarian dalam menjalani realitas kehidupan. Kehadiran seni hanya sebagai bagian dari pengalaman penting perjalanan kehidupan manusia. Sebagai contoh, dalam memperingati Proklamasi Republik Indonesia, sering diadakan lomba menyanyi antar lingkungan masyarakat. Pada saat itu, seni musik dan para musisi akan merasa terhormat ketika terlibat dalam kegiatan tersebut, baik sebagai pengisi acara maupun sebagai juri. Sesunggguhnya, kehadiran seni tidak hanya muncul dari pengalaman yang berkesan bagi manusia, tapi juga dari kebiasaan manusia sehari-sehari. Untuk itu, dapat dikatakan bahwa seni sebagai kebutuhan manusia yang tak mengenal batasan waktu, tempat, dan status (Triyanto, 2017).

Kesenian-kesenian yang ada tidak hanya sekedar menampilkan kreativitas dan ekspresi seni individu maupun kelompok, namun juga memiliki fungsi tertentu. Fungsi kesenian berupa fungsi pengungkapan emosional, hiburan, komunikasi, sosial budaya, dan religi. Fungsi-fungsi tersebut masih ada hingga sekarang dan terus dipertahankan, sebab masih didukung oleh masyarakatnya (Sumardjo, 2010). Selain memiliki fungsi, kesenian dalam masyarakat juga hadir sebagai kebutuhan dalam masyarakat itu sendiri. Soedarso (2006, p. 119) menjelaskan bahwa kehadiran karya seni didorong oleh kebutuhan praktis, kebutuhan spiritual, dan kebutuhan berkomunikasi pada sesama manusia. Kebutuhan manusia tidak hanya berupa mencari makan, berkembang biak, berhubungan dengan nenek moyangnya, serta berhubungan dengan kekuatan, misteri, serta kekayaannya (Muchtar 1992:29). Di sisi lain, wujud kehadiran spiritual dalam hidup manusia terutama seni telah menjadi prioritas utama yang disebut prioritas transenden (Sumardjo, 2010, p. 111).

Keterkaitan antara seni dan pendidikan seni merupakan suatu bagian yang utuh dan saling melengkapi, terutama dalam kajian seni. Dalam ilmu seni murni, seni dijadikan objek kajian yang penting dalam pengembangan seni itu sendiri sesuai dengan unsur pembentuknya. Berbeda dengan pendidikan seni yang menjadikan seni sebagai media atau alat pendidikan. Antara seni dan pendidikan seni dalam pendidikan dibedakan ke dalam 
dua pendekatan yakni pendekatan through art dan pendekatan in art. Kedua pendekatan tersebut dilaksanakan sesuai nilai intrinsik dan ekstrinsik dalam seni. Seni itu menyangkut penghayatan dan pemahaman (Sumardjo, 2000). Artinya, penghayatan didapatkan melalui pengalaman estetis, sedangkan pemahaman didapatkan melalui ilmu pengetahuan.

\section{Paradigma Pendidikan Seni Berbasis Karakter dalam Ma'badong}

Dalam pendidikan seni, posisi seni ada sebagai sarana pendidikan yang mengarah pada pengembangan potensi pribadi, sosial, dan budaya. Maka dari itu, pendidikan seni harus terselenggara dan terlaksana yang berbasis pada budaya. Menurut Salam (2001) bahwa pendidikan seni berlandaskan dua pertimbangan yakni kepentingan masyarakat dan kepentingan perseorangan. Artinya, pendidikan seni bertujuan memenuhi kebutuhan personal, kesadaran sosial, dan menyalurkan budaya (Chapman, 1978). Secara nasional, pendidikan seni bertujuan untuk mengembangkan daya kesadaran dan kepekaan estetik (apresiasi), daya cipta (kreativitas), dan memberi kesempatan berekpresi. Secara umum, peserta didik didorong untuk mengekspresikan gagasan-gagasan secara bebas. Adapun tiga tujuan pendidikan seni di sekolah berupa apresiasi, kreasi, dan ekspresi menjadi kesatuan dalam membentuk kepribadian yang sadar akan nilai-nilai sosial dan budaya (Triyanto, 2017). Fungsi pendidikan seni mengarah pada dua hal yakni media pendidikan estetik dan media pendidikan kreatif. Untuk itu, dapat dikatakan fungsi pendidikan seni bersifat ganda, karena pendidikan seni juga menjadi media pelestarian dan pewarisan nilai-nilai sosial budaya yang di dalamnya terkandung dimensi kognitif dan afektif.

Implementasi pendidikan seni berbasis karakter dapat dilihat pada fenomena ritual kematian Rambu Solo' dan Ma'badong yang terjadi di Kabupaten Tana Toraja Provinsi Sulawesi Selatan. Kata Rambu berarti "asap" sedangkan Solo' berarti “turun". Jadi, Rambu Solo' dipahami sebagai ritual masyarakat Toraja yang erat kaitannya dengan pemakaman atau kedukaan. Ritual ini merupakan salah satu paham animisme, karena seluruh kehidupannya dihubungkan dengan kepercayaan dan pemujaan kepada arwah nenek moyang (Sitonda, 2007, p. 48-49). Tujuan dari Rambu Solo' adalah mengantarkan arwah orang Toraja yang sudah mati menuju alam roh dan tinggal di puya bersama para leluhur (Turangan, dkk, 2014, p. 104). Ma'badong merupakan perpaduan gerak dan suara yang menceritakan ratapan dan harapan bagi orang yang sudah mati. Istilah Ma'badong berasal dari kata " $M a$ " yang berarti kegiatan atau aktivitas yang sedang berlangsung. Sedangkan 
"badong" berarti nyanyian atau lagu kematian. Secara umum, Ma'badong diartikan sebagai kegiatan bernyanyi yang dilaksanakan dalam upacara kematian.

Secara umum prosesi Rambu Solo' dan Ma'badong merupakan satu kesatuan yang utuh. Namun dalam kenyataannya tidak semua orang dapat mewujudkan prosesi Rambu Solo' dan Ma'badong. Hal ini dikarenakan prosesinya membutuhkan biaya yang cukup besar untuk satu kali prosesi Rambu Solo' yang di dalamnya terdapat ritual Ma'badong. Maka dari itu, ketika keluarga besar melakukan prosesi tersebut, keluarganya akan menjadi orang terpandang di sekitar tempat tinggalnya. Prosesi ini menjadi mahal karena adanya pengorbanan hewan kerbau yang harganya berkisar puluhan hingga ratusan juta untuk satu ekor kerbau. Di samping itu, pembuatan pondok dan konsumsi untuk para tamu dan orang yang bekerja pada prosesi tersebut membutuhkan biaya yang cukup besar. Ma'badong dipentaskan dengan membentuk sebuah lingkaran yang terdiri dari beberapa orang kaum laki-laki. Menurut Labuhari (1997, p. 40) badong adalah lagu atau nyanyian duka. Labuhari (1997, p. 34) mendefinisikan Ma'badong sebagai sebuah tarian dalam upacara kematian Toraja. Jadi secara keseluruhan Ma'badong adalah perpaduan gerakan tubuh (seni tari) dan nyanyian (seni musik).

Musik merupakan sebuah seni yang medianya berbentuk bunyi atau suara. Bunyibunyi yang dihasilkan dari suara manusia pada dasarnya berjalan dalam rentangan waktu tertentu atau dapat dikatakan mewaktu. Hal ini sependapat dengan yang diungkapkan oleh Miller (2017, p. 26) bahwa musik adalah suatu seni yang berada pada waktu; mediumnya adalah bunyi yang sebenarnya (ragawi), yang tidak menetap melainkan bergerak di dalam suatu rentangan waktu. Oleh karena itu, elemen-elemen waktu merupakan landasan bagi musik dan elemen ini dibagi ke dalam tiga faktor yaitu tempo, meter, dan ritme. Pendapat yang diungkapkan oleh Miller dapat dipahami bahwa musik pada dasarnya berjalan dalam rentangan waktu tertentu dan terbagi dalam tiga faktor.

Dalam Ma'badong sebagai sebuah ritual maupun kesenian tentunya mengandung nilai-nilai filosofi yang mendasari kehidupan suku Toraja sesuai dengan kepercayaan Aluk To'Dolo. Cahyono (2006, p. 1) menjelaskan bahwa kesenian bukan hanya tentang wujud yang ditransmisikan, melainkan mencakup nilai-nilai dan norma-norma yang dianut masyarakatnya. Nilai dan norma tersebut akan membentuk karakter seseorang. Nilai dan norma tersebut awalnya diterima dari orang tua yang kemudian diwariskan kepada anakanaknya sebagai landasan hidup. Potensi nilai karakter terhadap pendidikan karakter dalam musik vokal Ma'badong di Tana Toraja tentunya akan dilakukan oleh masyarakatnya. 
Lickona (2004, p. 4) mengatakan bahwa karakter manusia dan masyarakat turut berpartisipasi dalam kesejahteraan bangsa dan negara. Pendidikan yang tepat bukan hanya sekedar mendidik dan mengupayakan potensi peserta didik, tetapi juga menjadi media penanaman nilai-nilai (Sayono, dkk, 2015). Jadi, pendidikan karakter dalam musik vokal Ma'badong di Toraja Utara mengandung nilai-nilai filosofi suku Toraja yaitu nilai sopan santun, nilai tanggung jawab, nilai hormat, nilai cinta dan kasih, serta nilai rasa syukur. Kelima nilai-nilai tersebut sangat berpengaruh dalam proses pembentukan karakter suku Toraja. Karakter tersebut mulai dibentuk dari diri sendiri, kemudian dibentuk keluarga hingga munculnya karakter bangsa berbasis multikultural. Selain itu, nilai-nilai yang ada menjadi penyeimbang dalam proses kehidupan keluarga, masyarakat, serta bangsa dan negara.

\section{Kesimpulan}

Pendidikan seni dalam dunia pendidikan bukan untuk menonjolkan kecerdasan peserta didik, namun untuk membentuk moralitas. Kecenderungan paradigma masyarakat dalam memahami pendidikan khususnya di Indonesia masih mengarah pada sains, teknologi, dan ekonomi. Padahal, pendidikan tidak hanya berorientasi pada intelektual peserta didik, namun juga pada apresiasi, kreativitas, dan ekspresi diri peserta didik. Melalui pendidikan seni, daya apresiasi, kreativitas, dan ekspresi diri yang dipahami dan dihayati mampu mengembangkan karakter yang ada pada peserta didik sesuai dengan pengalaman hidupnya. Berbagai faktor yang menjadi kendala dalam pengembangan pendidikan seni berbasis karakter adalah kurangnya tenaga pendidik, sarana prasarana, dan kurikulum yang mendukung aktivitas pembelajaran.

Pendidikan seni dipandang sebagian besar oleh masyarakat sebagai pendidikan dalam mempersiapkan anak-anak untuk menjuarai lomba dan kompetensi seni. Hal ini yang mengakibatkan seni dianggap sebagai eksploitasi minat dan bakat seseorang. Padahal sesungguhnya setiap manusia mempunyai jiwa dan selera seni yang berbeda satu dengan lainnya. Oleh karena itu seni harus menjadi kebutuhan dasar dalam kehidupan manusia. Pendekatan pendidikan seni berbasis karakter diharapkan mampu mengatasi krisis moralitas yang sedang terjadi. Seperti yang dapat ditemukan pada musik Ma'badong yang menjadi media atau sarana pendidikan non-formal untuk menumbuhkembangkan potensi peserta didik, secara khusus pengembangan karakter atau budi pekerti. Seni dalam ritual dijadikan sebagai media pendidikan yang tidak hanya fokus pada usaha pengembangan 
intelektual individu, namun juga mengarah pada penanaman nilai-nilai yang sesuai dan dianut oleh masyarakat. Hal ini membuktikan bahwa pendidikan dapat berlangsung tanpa dibatasi oleh waktu, situasi, kondisi tertentu.

\section{Kepustakaan}

Bourdieu, Pierre. 1992. Language and Symbolic Power. Polity Press.

Cahyono, A. 2006. "Seni Pertunjukan Arak-Arakan Dalam Upacara Tradisional Dugdheran Di Kota Semarang." Harmonia 3:1-11.

Chapman, L. .. 1978. Approach to Art Education. New York: Harcout Brace Jovanovich.

Dewantara, Ki Hadjar. 1962. Pendidikan Nasional. Yogyakarta: Majelis Luhur Taman Siswa.

Feist, Jess dan Gregory J.Feist. 2010. Teori Kepribadian: Theories of Personality (Terj. Hendriatno). Jakarta: Salemba Humanika.

Foucault, Michel. 2012. Arkeologi Pengetahuan (Terj. Inyiak Ridwan Muzir). Yogyakarta: Ircisod.

French, Marilyn. 1985. Beyond Power: On Women, Men, and Morals. New York: Balliantine Books.

Hall, Calvin C. 1980. Suatu Pengantar Ke Dalam Ilmu Jiwa Sigmund Freud (Terj. S. Tasrif). Jakarta: PT. Pembangunan.

Jung, Carl Gustav. 1949. Psychological Type or the Psychology of Individualtion. London: Routledge \& Kegan Paul Ltd.

Kartodirjo, Sartono. 1990. Pengantar Sejarah Indonesia Baru: Sejarah Pergerakan Nasional (Vol. II). Jakarta: Gramedia.

Koentjaraningrat. 1990. Pengantar Ilmu Antropologi. Jakarta: Penerbit Rineka Cipta.

Kristanto, Alfa. 2019. "KONTEKSTUALISASI GAMELAN JAWA DI GEREJA BAPTIS INDONESIA ( GBI ) NGEMBAK.” Tonika 2(1):19-31.

Labuhari. 1997. Budaya Toraja. Jakarta: Yayasan Maraya.

Lickona, Thomas. 2004. Character Matters. New York: Somon \& Schuster.

Mayer, J.D. \& Cobb, C. D. 2000. "Educational Policy on Emotional Intelligence: Does It Make Sense?” Educational Psychology Review 12:163-83.

Miller, Hugh M. 2017. Apresiasi Musik. edited by Sunarto. Yogyakarta: Thafa Media Yogyakarta.

Muchtar, But. 1992. Seni Patung Dalam Kaitannya Dengan Kehidupan Manusia. edited by Soedarsono. Yogyakarta: ISI Yogyakarta dan TBY.

Perez, J.C.; Petrides, K. V.and Furnham A. 2005. Measuring Trait Emotional Intelligence. International Hand-Book of Emotional Intelligence. edited by R. and R. R. D. Schulze. Cambridge: MA: Hogrefe and Heber. 
Ratna, Nyoman Kutha. 2014. Peranan Karya Sastra, Seni, Dan Budaya Dalam Pendidikan Karakter. Yogyakarta: Pustaka Belajar.

Salam, S. 2001. Pendidikan Seni Rupa Di Sekolah Dasar. Makassar: Universitas Negeri Makassar.

Sayono, Joko, dkk. 2015. "Nilai-Nilai Pendidikan Karakter Dalam Dongeng Gagak Rimang." Jurnal Sejarah Dan Budaya 9 No. 2:236-56.

Sitonda, Mohammad Natsir. 2007. Toraja: Warisan Dunia. Makassar: Pustaka Refleksi.

Soedarso, Sp. 2006. Trilogi Seni: Penciptaan, Eksistensi, Dan Kegunaan Seni. Yogyakarta: ISI Yogyakarta.

Sumardjo, Jakob. 2000. Filsafat Seni. Bandung: ITB Bandung.

Sumardjo, Jakob. 2010. Estetika Paradoks. Bandung: Sunan Ambu Pres, STSI Bandung.

Suryabrata, Sumadi. 1988. Psikologi Kepribadian. Jakarta: CV. Rajawali.

Triyanto. 2017. Spirit Ideologis Pendidikan Seni. Semarang: Cipta Prima Nusantara.

Turangan, Lily.dkk. 2014. Seni Nasional. Jakarta: PT. Aku Bisa.

UPI, T. P. I. P. 2007. Ilmu Dan Aplikasi Pendidikan Bagian III: Pendidikan Disiplin Ilmu. Bandung: PT. Imperial Bhakti Utama. 